\title{
An index of municipality-level vulnerability to COVID-19 in Mexico.
}

\section{Índice de vulnerabilidad en municipios de México frente al COVID-19}

\author{
Avila-Ortega, Daniel Itzamna*a, Flores-Santana, Cynthia ${ }^{\mathrm{a}}$, Gómez-Hernández, Daniel ${ }^{\mathrm{b}}$ \\ ${ }^{a}$ Mexican Center of Industrial Ecology. Av. Hidalgo Ote. 63A, Z.P. 61506. Zitácuaro, Michoacán, México. \\ ${ }^{b}$ Facultad de Ciencias, Universidad Nacional Autónoma de México, Av. Universidad 3000, Circuito Exterior S/N, Delegación Coyoacán, C.P. 04510, Ciudad \\ Universitaria, Ciudad de México, México.
}

\begin{abstract}
In face to the novel COVID-19 and the high mortality ratio associated with different comorbidities in Mexico (and elsewhere), we identified the need to characterize the risk of regional population to COVID-19, exclusively as a result of their health status. With data from the 2018 National Health and Nutrition Survey (ENSANUT), we have calculated a vulnerability index that includes hypertension, diabetes, obesity, chronic renal insufficiency, smoking, and cardiovascular diseases, as well as age cohort and sex at the municipal level. With the vulnerability index we calculated the population at risk and, in combination with hospitalization beds, the population that can be effectively treated at each municipality. Although, COVID-19 has already hit Mexico, the index serves as a planning policy tool to implement preventive actions on those vulnerable regions. We show that, given unhealthy habits, the population at risk in Mexico is close to 78.2 million. Particularly, we observed that poor areas have less comorbidities than rich areas. However, they also have poorer access to health infrastructure which diminishes municipalities' resilience to COVID-19. Furthermore, highly populated municipalities appear to have a higher vulnerability index.
\end{abstract}

Keywords: COVID19; vulnerability; comorbidity; Mexico

\section{Resumen}

Frente al nuevo coronavirus (SARS-CoV-2, COVID-19) y la alta tasa de mortalidad asociada a diferentes comorbilidades en México, identificamos la necesidad de caracterizar el riesgo de la población a escala regional con respecto al COVID-19, como resultado exclusivo de su estado de salud. Con datos de la Encuesta Nacional de Salud y Nutrición 2018 (ENSANUT), hemos calculado un índice de vulnerabilidad que incluye hipertensión, diabetes, obesidad, insuficiencia renal crónica, tabaquismo y enfermedades cardiovasculares, así como una clasificación por rango de edad y sexo para todos los municipios de México $(2,457)$. Con el índice de vulnerabilidad se calculó la población en riesgo y, en combinación con las camas disponibles para hospitalización al inicio de la pandemia, la población que puede ser efectivamente tratada en cada municipio en un instante dado. Aunque el COVID-19 ya ha afectado a México, el índice sirve como una herramienta de política de planificación para implementar acciones preventivas en esas regiones vulnerables. Mostramos que, dados los hábitos poco saludables, la población en riesgo en México se acerca a los 78.2 millones. En particular, observamos que las áreas pobres tienen menos comorbilidades que las áreas ricas. Sin embargo, también tienen un acceso más deficiente a la infraestructura de salud, lo cual disminuye la resiliencia de los municipios al COVID-19. Además, los municipios densamente poblados parecen tener un índice de vulnerabilidad más alto.

Palabras clave: COVID19; vulnerabilidad; comorbilidad; México

\footnotetext{
(c) D. I., Avila-Ortega, C., Flores-Santana, D. Gómez-Hernández This is an Open Access article distributed under the terms of the Creative Commons Attribution License (https://creativecommons.org/licenses/by-nc-sa/4.0/), which permits non-commencial sharing of the work and adaptions, provided the original work is properly cited and the new creations are licensed under identical terms.

*E-mail address: d.avila@cmei.org.mx
}

\section{Introduction}

On December 31st, 2019, a cluster of pneumonia cases in Wuhan, China, was reported due to a novel coronavirus (SARSCoV-2, COVID-19). By the following month (January 13th, 2020), the first COVID-19 case outside of China was confirmed. Consequently, after a strong concern about the alarming spread 
and severity level of the novel virus, the World Health Organization decided to declare COVID-19 as a pandemic (WHO, 2020b).

Recent studies about COVID-19 patients, confirmed that age is one of the major risk factors, increasing the mortality rate in old patients (Arentz et al., 2020; Bedford et al., 2020; Erdely, 2020b, 2020a; Guan et al., 2020; Stevens, 2020). Further, different comorbidities proved to increase the risk, ergo the death chances, in sick patients (X. Yang et al., 2020; Zhou et al., 2020). The most common comorbidity has been hypertension, followed by cardiovascular disease, diabetes, and chronic respiratory system disease (Bedford et al., 2020).

In many cases, researchers also found that patients that enter the Intensive Care Unit (ICU) have more than one comorbidity (Arentz et al., 2020; Bedford et al., 2020; Chen et al., 2020; D. Wang et al., 2020; Erdely, 2020b, 2020a; J. Yang et al., 2020; X. Yang et al., 2020; Zhou et al., 2020). In this sense, some comorbidities prove to be more dangerous than others. That is the case of chronic obstructive pulmonary disease (COPD), which has a higher hazard ratio than diabetes, followed by hypertension (Guan et al., 2020). Guan et al. (2020) also found a higher hazard ratio in patients with two or more comorbidities than in patients with one comorbidity.

The first COVID-19 case in Mexico was declared on February 28,2020 , from someone who has had contact with a COVID19-confirmed Italian case (country with 17,669 deaths by this disease) (SSA, 2020c). To date, (August 28th, 2020), there are 536,620 confirmed cases with 58,481 deaths in Mexico (SSA, 2020c; WHO, 2020a). The first death in the country was a 41year-old man who had type 2 diabetes (a chronic non-communicable disease)(SSA, 2020c, SALUD México, 2020).

Related to the above, Mexican authorities seem to be aware that COVID-19 represents a big challenge given the health status of the population and of the hospital infrastructure. For the former, it is well known that overweight and obesity are a substantial public health issue in Mexico, which ranks worldwide among the highest in obesity rate (Stevens et al., 2008; PérezSalgado et al., 2012; Barquera et al., 2013; DiBonaventura et al., 2018; OECD, 2019b). According to the OECD, 72.5\% of the population above 15 years old are overweight in Mexico, with at least $15 \%$ reaching the category of obese (OECD, 2019b). The associated comorbidities that come with obesity in Mexico are prediabetes, type 2 diabetes, hypertension and cardiovascular disease (Stevens et al., 2008; DiBonaventura et al., 2018; SSA, 2018).

Cardiovascular diseases are the main cause of annual mortality (Rosas-Peralta and Attie, 2007), with approximately 141 thousand deaths for the year 2017, followed by diabetes mellitus (type 2) with 106.5 thousand (SSA, 2018). Historically, cardiovascular disease is more frequent in men than in women, and in people 45 years old and above (SSA, 2020d). On the other hand, diabetes is more common among women, with deaths occurring in patients as young as 25 years old. Patients under 15 years old die from cardiovascular disease mostly related to unhealthy lifestyles (Cordova-Villalobos et al., 2008).
Campos-Nonato et al. (2013) highlighted hypertension as a significant risk factor for patients with renal and cardiovascular diseases, commonly resulting in death. In 2012, it was estimated that $31.5 \%$ of young adults had hypertension in Mexico (Campos-Nonato et al., 2013). Although renal disease is the tenth cause of death in Mexico (13.8 thousand for 2018 (SSA, 2020d)), it is heavily related to different comorbidities such as obesity, diabetes, hypertension and cardiovascular disease, presenting a path-chain of diseases that ultimately reduces the quality of life of individuals (Stevens et al., 2008). Out of this path-chain, from 1994 to 2018, deaths by chronic obstructive pulmonary disease have increased by a factor of three, reaching 23.4 thousand people (SSA, 2020d). This process has mostly affected people above 45 years old, but especially men above 65 years old.

As the fourth largest country with obese people (OECD, 2019b), and the sixth country with type 2 diabetes in the world (FID, 2019) and the largest among OECD countries (OMS, 2016; OECD, 2019a), Mexico presents a high-risk profile in face to the novel COVID-19. On the other hand, contrary to European countries where older adults are more abundant, Mexico's population is relatively young (Parant, 1990), which could help to mitigate COVID-19 mortality.

The primary research objective of this work is to develop a municipality-level risk index for Mexico, aiming at identifying places with high vulnerability risk due to comorbidity's population and poor hospital infrastructure. The results could help to better plan the use of resources and to improve current critical care capacity.

\section{Methods}

\subsection{Age cohorts, population, and sex}

We retrieved population data classified by sex, municipality, and age cohorts from the National Population Council (CONAPO) for the year 2018 (CONAPO, 2019). The available age cohorts, in quintiles, were reclassified to match with the 2018 National Health and Nutrition Survey (ENSANUT)(INEGI and INSP, 2019) and the COVID-19 cases reported by the Mexican authorities for the time period between 28/02/2020 and 28/08/2020 (SSA, 2020c) (refer to Supplementary Information (SI) Table 1).

As indicated in Reference 1, the age cohorts from CONAPO were reclassified and grouped by a unique identifier, sex, and age cohort adding up the population. ENSANUT age data is available in months for children younger than 10-years old, and in years for teenagers and adults older than 10 and 18-years old, respectively. As such, we have added up groups of people based on the age of each persona available in ENSANUT, following the rules indicated in Reference 1. Finally, COVID-19 cases reported by the Mexican authorities were reclassified following the same rules represented in reference 1 . This procedure allowed us to harmonize three databases at the municipal level, to name CONAPO, ENSANUT and COVID-19 cases with the same age cohorts. 
Ref 1 .

age cohort $=\left\{\begin{array}{c}0 \text { to } 9 \\ 10 \text { to } 19 \\ 20 \text { to } 29 \\ 30 \text { to } 39 \\ 40 \text { to } 49 \\ 50 \text { to } 59 \\ 60 \text { and more }\end{array}\right.$

Given that COVID-19 is more aggressive with older adults (Erdely, 2020b, 2020a), we assumed that the risk of death increases with age. As such with the age cohorts previously established, we proceeded to assign each one of them a score $\left(S_{a}\right.$ meaning Age Score) following equation 1. This equation allowed us to split one-hundred points, with a risk quota that decreases with age (refer to Supplementary Information Table 2).

$$
S_{a}=\frac{\left(\frac{100}{2^{n}}\right)}{100}
$$

With $n$ equal to the index per age-cohort in decreasing format, equation 2, and $S_{a}$ as the score per age cohort.

$$
n= \begin{cases}0 \text { to } 9 & : 7 \\ 10 \text { to } 19 & : 6 \\ 20 \text { to } 29 & : 5 \\ 30 \text { to } 39 & : 4 \\ 40 \text { to } 49 & : 3 \\ 50 \text { to } 59 & : 2 \\ 60 \text { and more } & : 1\end{cases}
$$

Various authors (Bwire, 2020; Chen et al., 2020; Erdely, $2020 \mathrm{~b}, 2020 \mathrm{a}$ ) have reported that COVID-19 is more common in males than females; this is the case in Mexico (SSA, 2020c). The available data until 28/08/2020 shows that out of 537,031 sick people $53 \%$ were male, and $47 \%$ were female. We have assumed that males have twice the risk of being sick than females, with a share of $2 / 3$ of the cases and females of $1 / 3$ (see equation 3), where $S_{s}$ means Sex Score.

$$
S_{s}= \begin{cases}\text { Male } & 0.67 \\ \text { Female } & 0.33\end{cases}
$$

\subsection{Comorbidities and comorbidity index}

Based on the technical report presented daily by the Mexican authorities, it was recovered that until 01/04/2020 (SSA, $2020 \mathrm{c}$ ), hypertension (48.56\%), diabetes $(45.95 \%)$, obesity ( 40 . $54 \%)$, chronic obstructive pulmonary disease $(18.92 \%)$, chronic renal insufficiency $(16.22 \%)$, smoking $(5.41 \%)$, cardiovascular disease $(5.41 \%)$ and immunosuppression $(5.41 \%)$ were the most common comorbidities in COVID-19 deaths.
Considering this information, we have collected hypertension, diabetes, obesity, chronic renal insufficiency, smoking, and cardiovascular disease data at the State level for year 2018 from the 2018 National Health and Nutrition Survey (NHNS)(INEGI and INSP, 2019). Chronic obstructive pulmonary disease and immunosuppression data were not available in any governmental database, therefore these two comorbidities have been excluded from the comorbidity and vulnerability index. We have decided to proceed with the available data given that various authors have reported the most common comorbidities in COVID-19 cases in Wuhan, China and Lombard Italy to be hypertension, cardiovascular disease, type 2 diabetes and chronic kidney disease (Grasselli et al., 2020; Guan et al., 2020; J. Yang et al., 2020; T. Wang et al., 2020). Furthermore, we also considered the high levels of obesity and diabetes that Mexico presents (Rtveladze et al., 2014; FID, 2019; OECD, 2019a).

For the selected comorbidities, we have constructed an individual score ranging from zero to one, which was later used to calculate the comorbidity $C I$ and vulnerability $V I$ indices. Each comorbidity score $(S)$ was constructed per age cohort $(j)$, sex $(k)$, chronic disease $(l)$ and municipality $(i)$ following equation 4.

$$
C I_{i, j, k}=\frac{S a_{j, k}+\sum_{n=1}^{n=7} S_{j, k, l, i}}{7}
$$

In order to fill in the variables for each age cohort, sex, comorbidity, and municipality from equation 4 , we have collected data on chronic diseases from NHNS (INEGI and INSP, 2019). In the case of kids from 0 to 9 years old, we have assumed that people living in this age cohort do not present any comorbidity in any municipality. Hence, the comorbidity scores were set to zero.

For teenagers between 10 to 19 years old, it was only feasible to recover from NHNS smoking and obesity data at the State level (INEGI and INSP, 2019). For the former, from the available key-code catalog from NHNS, (refer to SI Table 3), we filtered as non-smokers those that followed the rules represented in supporting equation (SE) 1 in SI. The resulting nonsmokers were subtracted from the available observations and grouped by sex and State.

For non-obese teenagers, we applied the filtering rules available in supporting equation 2 in SI. These were also subtracted from the available observations and grouped by sex and State. For adults above 20 years old, comorbidities were filtered among those that, in fact, have them and those that do not as reported by the NHNS. For instance, comorbidities were cleared following the rules described in supporting equations in SI, for nonobese in SE 3; non-diabetic in SE 4; hypertensive in SE 5; cardiovascular in SE 6; renal in SE 7; smoking in SE 8. Finally, all comorbidities were grouped by age cohort, sex and State.

Once comorbidities were classified per age cohort and State, the datasets were merged. People $P$ with chronic diseases $l$ were 
downscaled from the State level $h$ to the municipal $i$, per sex $k$ level, following equation 5 .

$$
P_{h, i, j, k, l}=P_{h, j, k} \cdot \% \text { Pop_state_age }
$$

where the population $P$ with a given comorbidity $l$ in $h$ State, $i$-municipality, $j$-age cohort, and $k$-sex, equals the population $P$ of the same cohort $j$, sex $k$ and State $h$ times the percentage of people in the same age cohort and sex at the given State, equation 6 .

$$
\% \text { Pop_state_age }=\frac{P_{h, i, j, k}}{\sum P_{h, j, k}}
$$

For each comorbidity descriptive statistics were calculated, refer to Supplementary Information Table 4, based on age cohort and sex, reference 2 .

Ref 2.

$$
\begin{aligned}
& \text { stats }=P_{j, k, l} \\
& \text { stats }=\left\{\begin{array}{c}
\mathrm{n} \\
\mu \\
\bar{x} \\
\sigma \\
\text { QU1, QU2, QU3, QU4, QU5 }
\end{array}\right.
\end{aligned}
$$

We used the descriptive statistics, $0 \%, 25 \%, 50 \%$ (median), $75 \%$, and $100 \%$ distribution of the population with a chronic disease, to calculate the comorbidity score. As such, each entry - state, municipality, age, and sex - was categorized with an assigned score that depends on the descriptive statistics of given comorbidity across municipalities in the country, equation 7 .

$$
S l_{h, i, j, k}= \begin{cases}0, & P_{i, j, k, l}=0 \\ 0.25, & P_{i, j, k, l}>\text { QU1 and } P_{i, j, k, l}<\text { QU2 } \\ 0.5, & P_{i, j, k, l}>\text { QU2 and } P_{i, j, k, l}<\text { QU3 } \\ 0.75, & P_{i, j, k, l}>\text { QU3 and } P_{i, j, k, l}<\text { QU4 } \\ 1, & P_{i, j, k, l}>\text { QU4 and } P_{i, j, k, l} \leq \text { QU5 }\end{cases}
$$

The comorbidity index was finally calculated as the average of the sum of the age cohort score plus the comorbidity score (equation 4).

\subsection{Vulnerability index and adjusted vulnerability index}

The vulnerability index $V I$ reflects the risk that a given municipality faces COVID19, with regards to the status - age and disease wise - of its population. As such, we have calculated it as the weighted average of the score per sex and the comorbidity index $C I$, on an age-cohort and municipality basis (equation $8)$.

$$
V I_{h, i}=\frac{\sum_{h, i, j}^{n=7}\left(S s_{k} \cdot C I_{h, i, j, k}\right)}{\sum_{j, k}^{n=7} S s}
$$

Additionally, we have calculated an adapted vulnerability index VI-A, that reflects the access to health services by the population of a given municipality, equation 9 . Health services access were collected from the National Council for the Evaluation of Social Development Policy (CONEVAL)(CONEVAL, 2019) on a municipal, age, and sex basis. The age cohort classification followed the same criteria described above, in order to match it with the comorbidities and age-municipality distribution. Whereas the score was calculated following reference 2 and equation 7.

$$
V I-A_{h, i}=\frac{\left(V I_{h, i, j, k}+S h a_{h, i, j, k}\right)}{2}
$$

\subsection{Population at risk and access to infrastructure}

From the Catalog of the Unique Code of Health Establishments (CLUES) (SSA, 2020b), we recovered the number of beds from private and public hospitals. Given that COVID-19 worst cases must be hospitalized, we have decided only to use those beds ready for hospitalization. Hence, we have calculated beds per thousand inhabitants as shown in equation 10 .

$$
b \times 1000=\frac{P O P_{h, i}}{T o t-b e d s_{h, i}}
$$

The total population of a given municipality $i$ and State $h$, that may be exposed to severe damage from COVID-19, results from multiplying the vulnerability index VI by the population, as shown in equation 11 .

$$
P A R_{h, i}=V I_{i, j} \cdot P O P_{h, i}
$$

This population may or not have access to beds or hospitalization, given the current hospital infrastructure and medical staff, ergo people that can be effectively treated is the result of the population at risk PAR times the beds' availability $b \times 1000$ (equation 12). With $P A I$ as the population with access to infrastructure per State $h$ and municipality $i$.

$$
P A I_{h, i}=P A R_{h, i} \cdot b x 1000_{h, i}
$$

Finally, we proceeded to perform two Pearson correlation analyses with effective COVID-19 cases, the vulnerability index and comorbidities at the municipal level. The first correlation analysis was taking into account all COVID-19 cases and 
the vulnerability index. Whereas, the second correlation analysis considered comorbidities in COVID-19 cases, in combination with the vulnerability index per municipality.

For the first correlation analysis, we normalized COVID-19 cases $C$ with the population of each municipality $i$, as shown in equation 13.

$$
\text { Normalization }-A_{i}=\frac{C_{i}}{P O P_{i}}
$$

Whereas for the second normalization, we normalized present comorbidities $l$ in COVID-19 cases $C$, against the total COVID19 cases $C$ per municipality $i$, as shown in equation 14 .

$$
\text { Normalization }-B_{i}=\frac{C_{l, i}}{C_{i}}
$$

\section{Results}

We assembled a comorbidity index (CI) based on six chronic diseases - hypertension, diabetes, obesity, chronic renal insufficiency, smoking and cardiovascular - in addition to the age cohort the population belongs to. With the CI, we then put in place a vulnerability and adjusted vulnerability indices, that considered sex and access to health services, respectively, at the municipal level.

We observed that the CI alone increased with age and was similar among males and females. Once it was grouped by sex, most of the time it was twice as much in males than in females, which is ultimately related to the weight given to men, as a risker profile in equation 3 . Nevertheless, when the vulnerability index (VI) was calculated, both males and females were associated with similar values. An interactive version of the VI map can be found here.

Our findings show that 449 municipalities present a VI between 0 and $0.2,689$ in the range of 0.2 to 0.4 , with many municipalities above 0.4 and below 0.6 (776), and only about 543 above 0.6 but below 0.8 . When considering the adjusted vulnerability index, $\sim 30 \%$ of the municipalities are between 0.4 and 0.6 , with more than $50 \%$ of the municipalities in the range of 0.4 to 0.6 . The remaining $20 \%$ is distributed in the ranks 0.6 to 0.8 and 0.8 to 1 (supplementary figure 1 in SI).

Except for the States of Oaxaca, Yucatan, Sonora, and Chihuahua, all the states in the country are characterized by a high count of municipalities with high VI. When the VI is adjusted for access to health infrastructure, there is a clear increase in vulnerability across all municipalities in the country, (Figures 1 and 2).

Disaggregating the information per sex and State, we can observe that in the State of Mexico 5.7 million female (F) and 5.3 millon male $(\mathrm{M})$ are in considerable risk, which are close to $65 \%$ of the state population. Mexico City follows it with $3.1(\mathrm{~F})$ and $2.9(\mathrm{M})$ million (67\%-pop), and Veracruz lies in the third place with $2.6(\mathrm{~F})$ and $2.4(\mathrm{M})$ million (60\%-pop).
As a whole, eight States (State of Mexico, Mexico City, Veracruz, Jalisco, Puebla, Guanajuato, Chiapas, and Nuevo Leon) that account for half the population in the country, present the higher risks in face to COVID-19. Inversely, less populated states such as Colima, Baja California Sur, Campeche, Tlaxcala, and Nayarit show the lesser population in risk associated with comorbidities (Figure 3).

In term of population at risk across the country, State of Mexico shows the largest share (14\%), followed by Mexico City (7.8\%), Jalisco (6.5\%), Veracruz (6.4\%), Guanajuato (5.2\%) and Puebla (4.9\%) (supplementary Figure 2 in SI). We have calculated available hospitalization beds per thousand inhabitants (bx1000), per municipality and State (supplementary Figure 4 and supplementary table 1 in SI). It is important to note that, perhaps, hospitalization beds will not be fully available for patients with COVID-19 alone.

Hence, considering available bx 1000 , it is possible to infer that the distribution does not coincide with the most populous States. The State (bx1000 | Total beds) with the highest bx1000 is Oaxaca $(0.1432 \mid 2,870)$, followed by Puebla $(0.0908 \mid 7,912)$, Veracruz $(0.0725 \mid 7,139)$, Michoacán $(0.067 \mid 5,103)$ and State of Mexico $(0.06358 \mid 12,365)$. We observed that, although more densely-populated states have many beds, such as Mexico City $(23,213)$ or State of Mexico $(12,365)$, its coefficient is rather low once it is shared with non-COVID patients among the citizens (supplementary Figure 4 in SI).

With the population at risk given comorbidities, age cohort, and sex in combination with the available beds per municipality, we estimated the population that effectively has access to health services (PAI). Mexico City can assist more patients $(15,631)$, followed by the State of Mexico with 8 thousand (k), Jalisco with $6 \mathrm{k}$, Puebla with $5 \mathrm{k}$, and Veracruz with $4.5 \mathrm{k}$. The States that can assist fewer people are Zacatecas with capacity for only 652 inhabitants, followed by Baja California Sur (661), Colima (718), Campeche (729), Nayarit (835), and Tlaxcala (853) (supplementary Table 6 in SI).

Considering the adjusted vulnerability index the available beds per municipality increase in Baja California to $24 \%(3,529)$, Mexico City to $23 \%(19,149)$, Nuevo Leon to $21 \%(5,344)$, Jalisco to $21 \%(7,495)$, Yucatan to $31 \%(2,143)$ and Durango to $10 \%(1,617)$. Inversely, there is a reduction to $9 \%$ in Tlaxcala (774), and 5\% in Zacatecas (620). Assuming the hospitalization beds are fully available for COVID-19. The percentage of beds in use changes in all states, oscillating between $60 \%$ to $80 \%$, except for Oaxaca and Tlaxcala (supporting Figure 4 and table $5 \mathrm{SI})$.

In Figure 5, it is possible to observe that the resulting correlation analysis yielded a rather small positive correlation $(0.24)$ between the COVID-19 cases and the vulnerability index. The low p-value, expresses that both variables are significant. The same can be observed for the second correlation analysis involving each comorbidity - included in the vulnerability index - and the vulnerability index itself. Correlations were rather small in all the cases with negative values for renal disease ($0.035)$, obesity $(-0.13)$, diabetes $(-0.13)$, hypertension $(-0.11)$ 


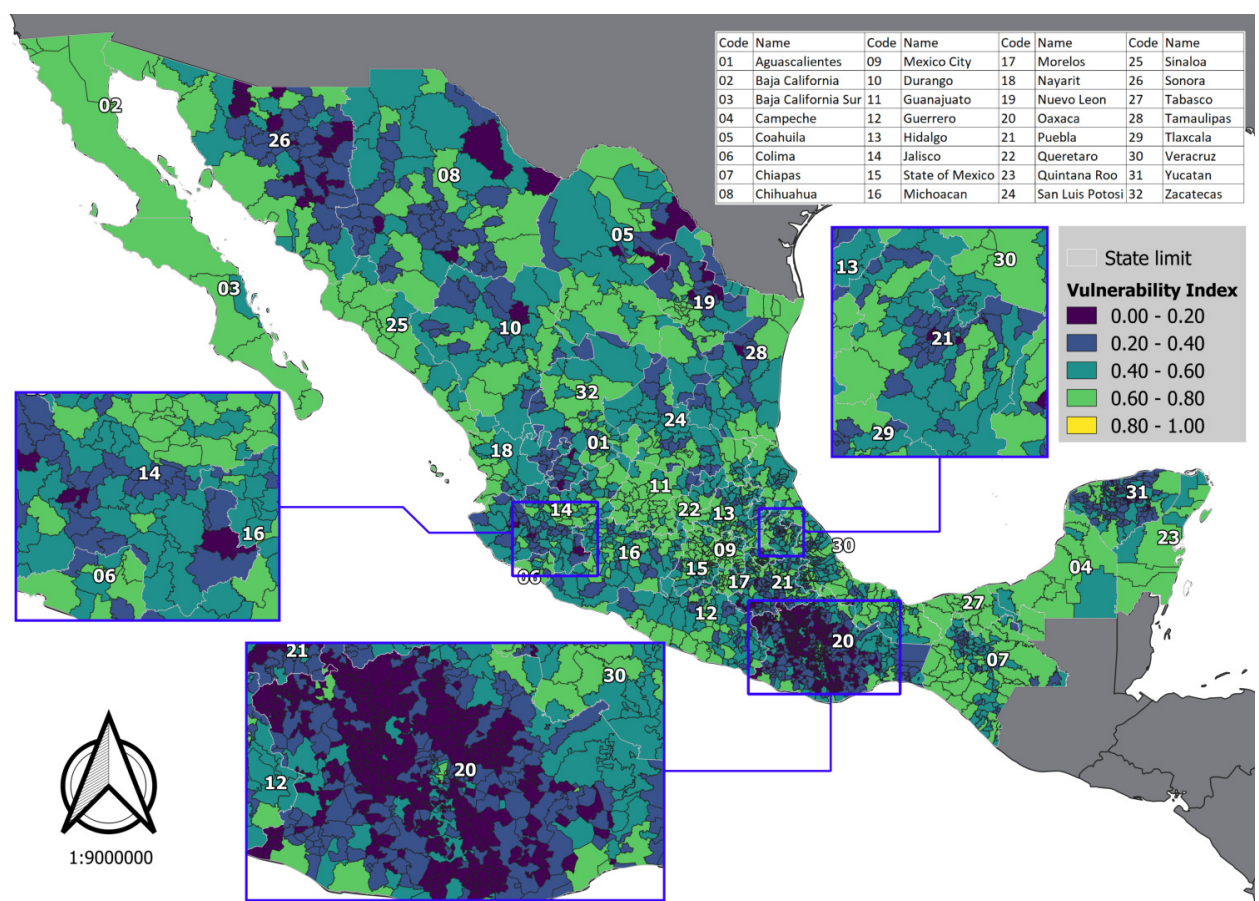

Figure 1: Vulnerability index at the municipal level in Mexico. CRS WGS84 in meters. Color classification is darker for lower vulnerability index, while lighter for higher. Numbers on the map refer to State names in Mexico as catalogued by INEGI. / CRS WGS84 en metros. La clasificación de color es más oscura para un índice de vulnerabilidad más bajo, mientras que más clara para un índice de vulnerabilidad más alto. Los números en el mapa se refieren a los nombres de los estados en México catalogados por el INEGI.

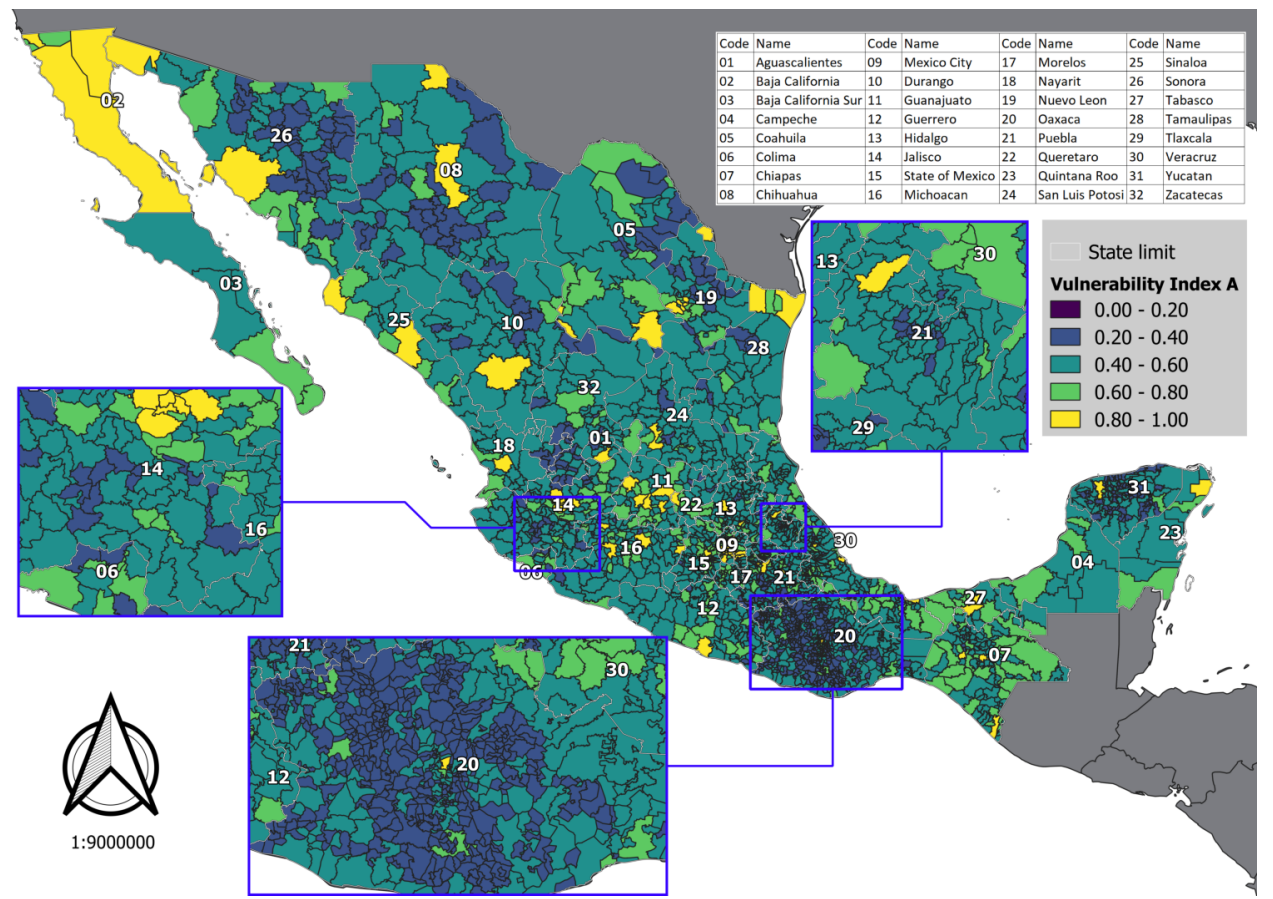

Figure 2: Adjusted vulnerability index at the municipal level in Mexico. CRS WGS84 in meters. Color classification is darker for lower vulnerability index, while lighter for higher. Numbers on the map refer to State names in Mexico as catalogued by INEGI. / CRS WGS84 en metros. La clasificación de color es más oscura para un índice de vulnerabilidad más bajo, mientras que más clara para un índice de vulnerabilidad más alto. Los números en el mapa se refieren a los nombres de los estados en México catalogados por el INEGI. 


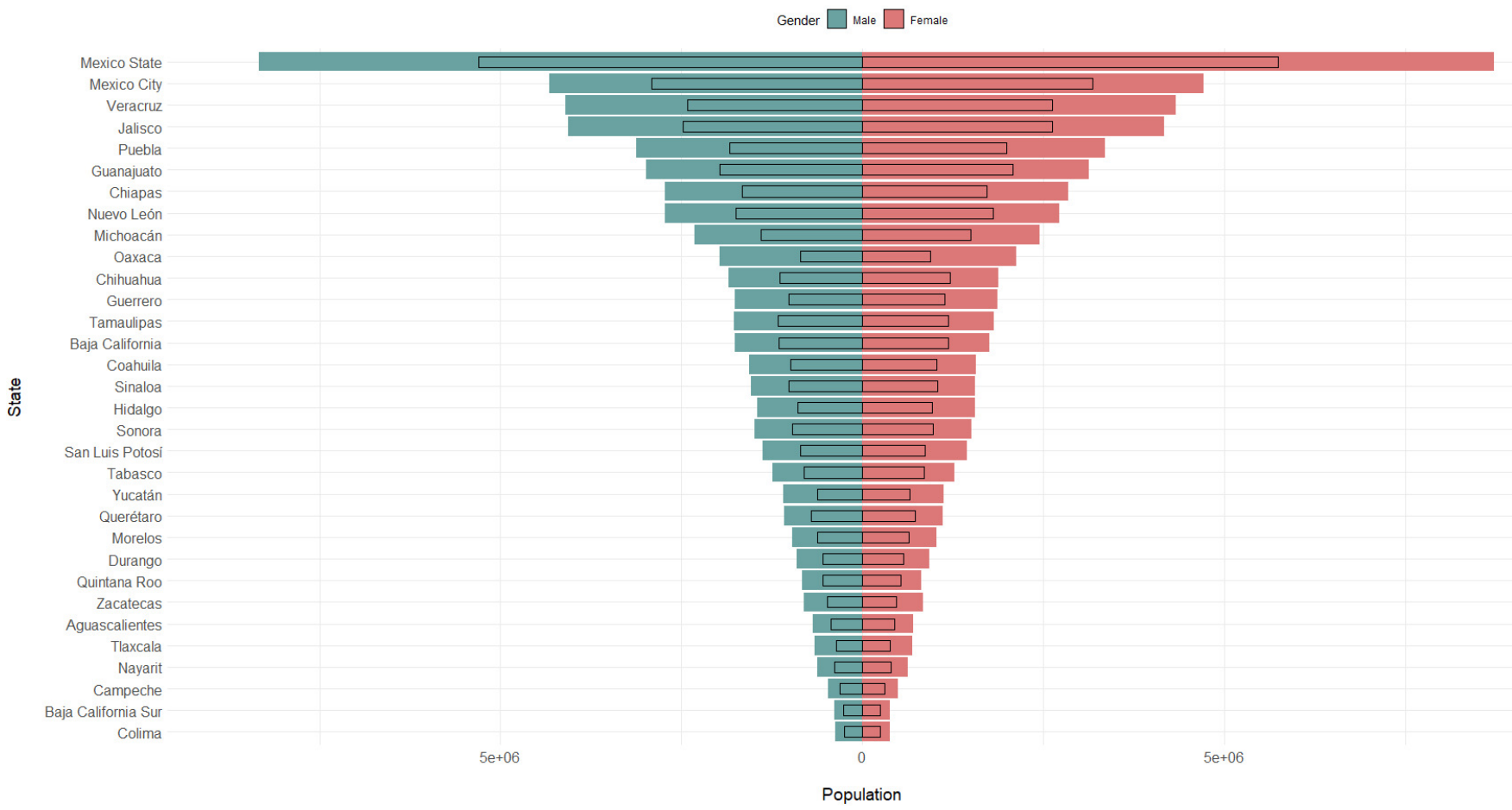

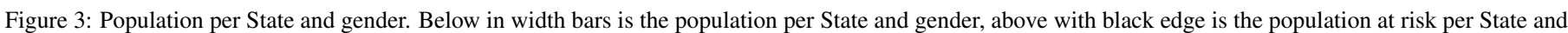
gender. Gender classification follows color for both variables. / Las barras de abajo representan la población por estado y género, las de arriba (con borde negro) representan la población en riesgo por estado y género. La clasificación de género sigue el color para ambas variables.

and cardiovascular disease (-0.079); and only positive for smoking (0.0039) (refer to supporting Figure 5 and supporting Table 8 for full detail).

Our findings show that Mexico faces a significant risk with the COVID19 pandemic for various reasons. First, the high rate of overweight among the population which in turn evolves into obesity and different comorbidities. Second, the high levels of type 2 diabetes that comes alone or in combination with obesity, cardiovascular disease, hypertension, and in some cases chronic renal insufficiency. These risk factors are partly decreased by the high level of young people in the country. Nevertheless, if trends continue along the same pattern, in the coming future all these young inhabitants will put a burden on the health system as a result of the different comorbidities (SSA, 2018; OECD, 2019b).

Our index could not take into account chronic obstructive pulmonary disease and immunosuppression because they are lacking at the municipal level. In this regard, the government should pay attention to ensure the availability of these data for future research on health, epidemiology, and pandemics.

\section{Discussion}

Knowing the vulnerability index, as well as the adjusted one proposed here, could have helped municipalities in taking action at an early stage of the pandemic. Checking these indexes would have helped in developing precautionary actions to protect the local population, the health infrastructure system and the medical staff. Nonetheless, municipalities still can make use of the vulnerability index and the available datasets from this work to put in place sanitary practices to deal with COVID19.

Furthermore, having access to health data - comorbidities - at the municipal level is useful for a wide range of professionals. For instance, medical and policy practitioners could observe what could be the need of medical equipment in the near future, in order to attend the sick population. Teachers and fathers can influence the alimentary habits that in the long-term make their families less prone to sickness, such as type 2 diabetes.

With the vulnerability index we calculated the population at risk given certain comorbidities across Mexico. By the end of August (August 28th, 2020), only 536,620 people were sick, and only about 58,481 had died. When this work was submitted (April 14th, 2020), there were 2,785 confirmed cases with 141 deaths in the country. Although the increase in cases seems scary over this four-month period, taking into account what the vulnerability index considers as a vulnerable population (78.2 million), the outcome seems not too serious. Nevertheless, we may have overestimated the vulnerable population given that the index is unable to reflect if a single person has more than one comorbidity, thus probably decreasing the number of sick people per municipality.

The correlation analyses showed rather small values when normalized effective COVID-19 cases were compared versus 


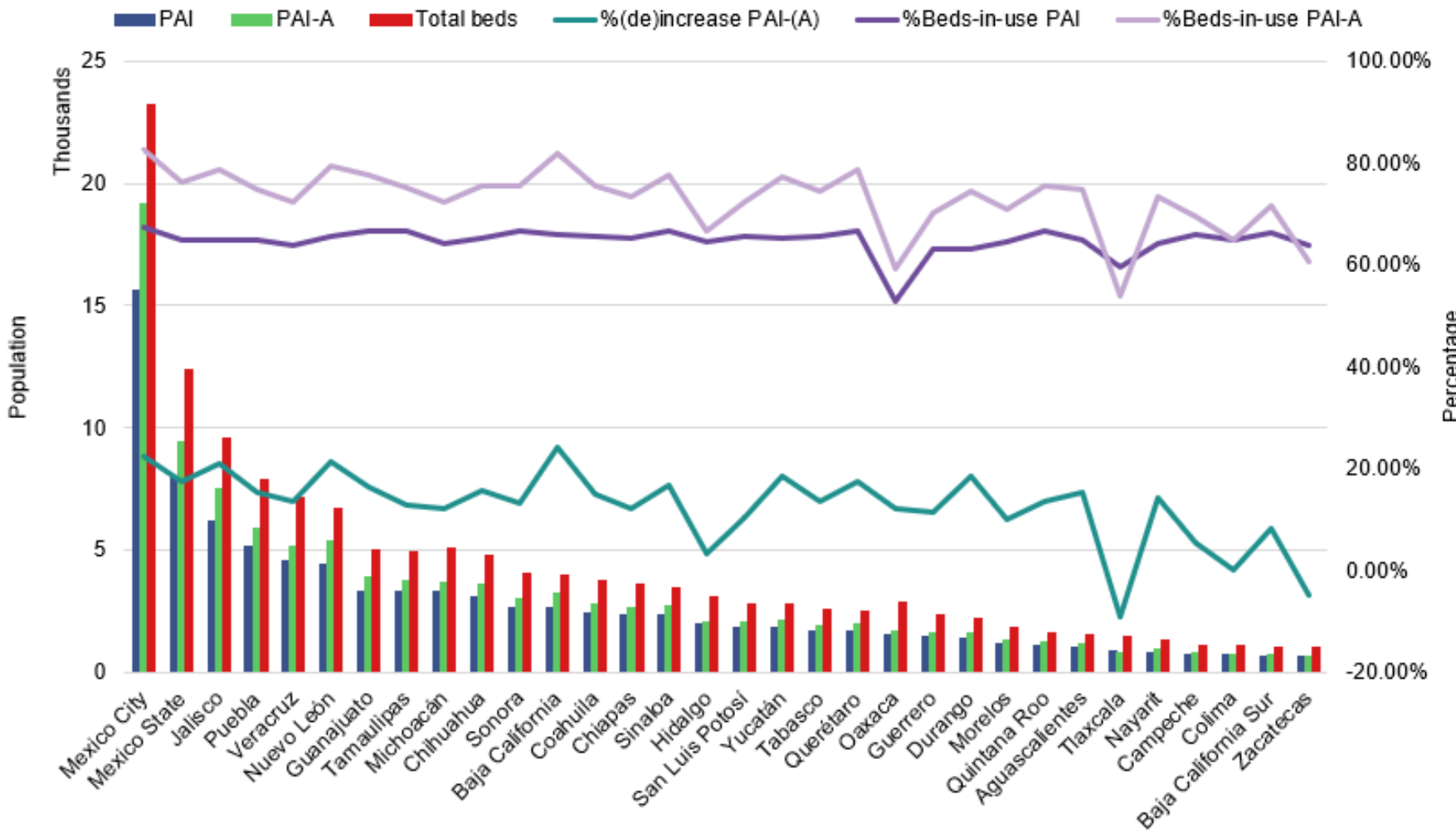

State

Figure 4: State summary for population with access to infrastructure and beds. PAI = population with access to infrastructure; PAI-A = population with access to infrastructure from adjusted vulnerability index; Total hospitalization beds available; \%(de)increase PAI-(A) = percentage of decrease/increase population with access to infrastructure; \%Beds-in-use PAI = percentage of hospitalization beds in use under PAI; \%Beds-in-use PAI-A= percentage of hospitalization beds in use under PAI-A. Data in SI tables 6 and 7. / PAI = población con acceso a infraestructura; PAI-A = población con acceso a infraestructura a partir del índice de vulnerabilidad ajustado; Total de camas de hospitalización disponibles; \% (de)incremento PAI- (A) = porcentaje de disminución / aumento de población con acceso a infraestructura; \% De camas en uso PAI = porcentaje de camas de hospitalización en uso bajo PAI; \% De camas en uso PAI = porcentaje de camas de hospitalización en uso bajo PAI-A. Datos en las tablas SI 6 y 7.

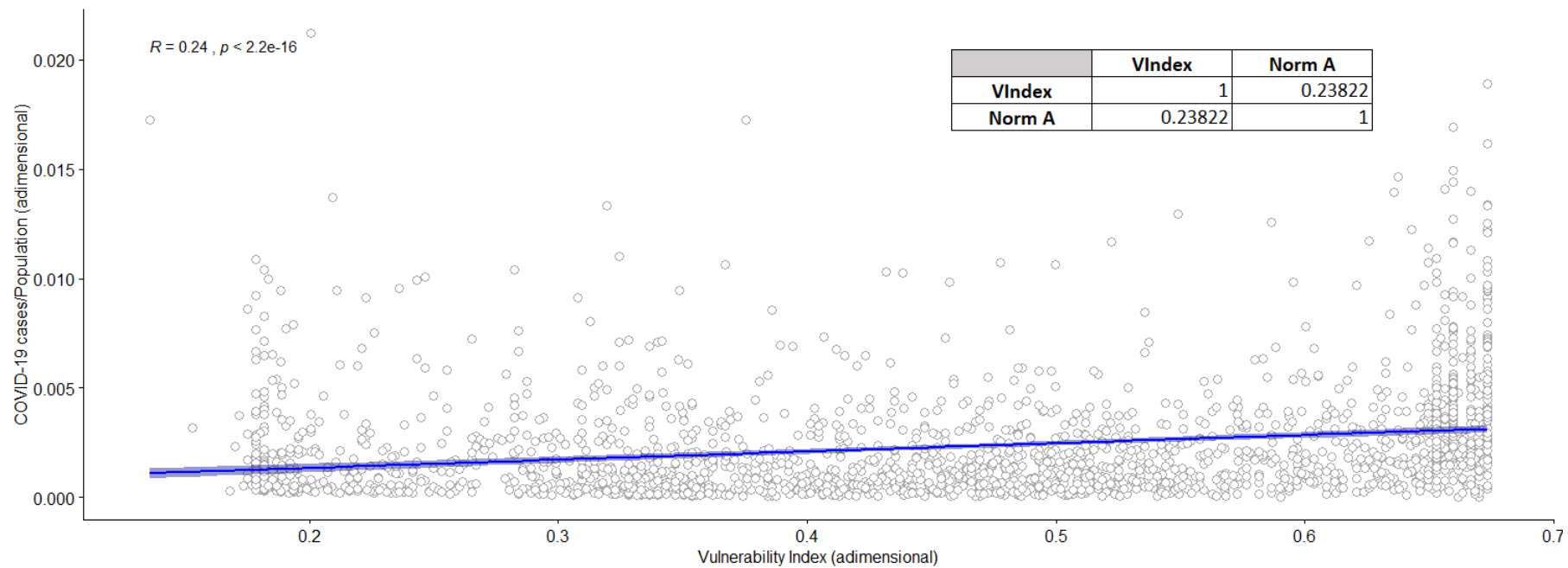

Figure 5: Pearson correlation analysis of effective COVID-19 cases and the Vulnerability Index. In the top-left it is possible to appreciate the correlation (R) between variables. 
the vulnerability index and when each comorbidity was also compared to the vulnerability index. In this respect we consider that: i) the index may overestimate the population at risk in a given municipality given the lack of comorbidities combination among the population; and ii) there may be an underestimation in the amount of positive COVID-19 cases, given the very low number of tests applied in Mexico. In fact, it has been estimated that the actual deaths related to COVID-19 may be nearly four times those reported by Mexican authorities, with numbers as high as 130,000 excess deaths in the country (Proyecto Li et al., 2020). Taking into account only Mexico City, Romero Zavala and Despeghel (2020) estimated that deaths are at least $112 \%$ higher than in 2019 , for the same period that the pandemic has last (with a total count of 38,690 deaths - at least $66 \%$ of country-wide confirmed deaths).

With this exploratory analysis of comorbidities at the municipal level, we would like to urge the authorities and the society to rethink the way the Mexican population nurtures and takes care of its health, since if the trend continues the burden to the health system may be considerably heavy.

\section{Conclusions}

The vulnerability and adjusted vulnerability indices presented in this work are useful in terms of assessing the danger of a given municipality with regards to the associated risk that $\mathrm{COV}$ ID-19 poses on the local population from both a health-wise and a health-infrastructure approaches.

Although the Government established a quarantine period, in order to "flatten the contagious curve" (Anderson et al., 2020; SEGOB, 2020) at an "early stage" of the pandemic, in some areas this practice was not followed. Particularly people outside large urban centers did not change too much their daily routines, increasing the risk of getting sick and spreading the disease. Nonetheless, people at the individual level followed patterns of self-protection like wearing masks, washing their hands, and so on, that in turn decreased considerably the share of sickness and death.

With the vulnerability index and the assessment of comorbidities and health infrastructure at the municipal level, the government can identify burdens to the system in order to put in place preventive actions, from a health and infrastructure point of view. Within this line of action, the government set in place the DN-III Plan overseen by the Military Forces (SSA, 2020a). Even with this further increased capacity, the maximum people the DN-III Plan could attend are close to 14,000 inhabitants across the country. In total, the government would be able to attend 104,404 people, assuming all medical resources and beds are put into COVID-19.

Analyzing the available data released by the Mexican authorities (SSA, 2020c) by 28/08/2020, we identified that representative comorbidities in death patients were hypertension $(44.20 \%)$, diabetes $(38.06 \%)$, obesity $(24.53 \%)$, chronic obstructive pulmonary disease $(4.73 \%)$, chronic renal insufficiency $(6.81 \%)$, smoking $(7.98 \%)$, cardiovascular disease $(5.30 \%)$ and immunosuppression (2.54\%). Except for obesity, chronic obstructive pulmonary disease, and chronic renal insufficiency the percentages do not differ much from the available information in April.

Finally, this study could be easily reproduced by scholars from other countries. This would allow comparing comorbidities and vulnerability indices, serving as a tool for policy planning in face to COVID-19 or other future forthcoming pandemics.

\section{Acknowledgements}

We thank two anonymous colleagues for reading the first version of this manuscript. Ph.D. Rigoberto Garcia-Ochoa for discussing the original idea of the score. MD-Ph.D. Jose Rodriguez Cruz for explaining the different characteristics of comorbidities. MSc. Georgios Kantidakis for his insights into the age and sex score. Ph.D. Irving Morales for his insights on normalization and further discussion on the index.

\section{Funding}

The authors received no financial support for the research, authorship, and/or publication of this article.

\section{Contributions}

A-O.D.I and F-S.C. designed the research, wrote the article and searched equally for data sources. A-O.D.I process all databases and made the plots and static maps. G-H.D. made the interactive maps.

\section{References}

Anderson, R. M., Heesterbeek, H., Klinkenberg, D., Hollingsworth, T. D., 2020. How will country-based mitigation measures influence the course of the COVID-19 epidemic? The Lancet 395 (10228), 931-934, https://doi.org/10.1016/S0140-6736(20)30567-5.

Arentz, M., Yim, E., Klaff, L., Lokhandwala, S., Riedo, F. X., Chong, M., Lee, M., 2020. Characteristics and Outcomes of 21 Critically Ill Patients With COVID-19 in Washington State. JAMA 323 (16), 1612-1614, https://doi.org/10.1001/jama.2020.4326.

Barquera, S., Campos, I., Rivera, J. A., 2013. Mexico attempts to tackle obesity: the process, results, push backs and future challenges. Obesity Reviews: An Official Journal of the International Association for the Study of Obesity 14 Suppl 2, 69-78, https://doi.org/10.1111/obr.12096.

Bedford, J., Enria, D., Giesecke, J., Heymann, D. L., Ihekweazu, C., Kobinger, G., Lane, H. C., Memish, Z., Oh, M.-d., Sall, A. A., Schuchat, A., Ungchusak, K., Wieler, L. H., 2020. COVID-19: towards controlling of a pandemic. The Lancet 395 (10229), 1015-1018, https://doi.org/10.1016/S0140-6736(20)30673-5.

Bwire, G. M., 2020. Coronavirus: Why Men are More Vulnerable to Covid19 Than Women? SN Comprehensive Clinical Medicine 2 (7), 874-876, https://doi.org/10.1007/s42399-020-00341-w.

Campos-Nonato, I., Hernández-Barrera, L., Rojas-Martínez, R., Pedroza, A., Medina-García, C., Barquera-Cervera, S., 2013. Hipertensión arterial: prevalencia, diagnóstico oportuno, control y tendencias en adultos mexicanos. Salud Pública de México 55, S144-S150, http://www.scielo.org.mx/scielo.php?script=sci_abstract\&pid=S0036$36342013000800011 \& \operatorname{lng}=\mathrm{es} \& \mathrm{nrm}=\mathrm{iso} \& \operatorname{tng}=\mathrm{es}$. 
Chen, N., Zhou, M., Dong, X., Qu, J., Gong, F., Han, Y., Qiu, Y., Wang, J., Liu, Y., Wei, Y., Xia, J., Yu, T., Zhang, X., Zhang, L., 2020. Epidemiological and clinical characteristics of 99 cases of 2019 novel coronavirus pneumonia in Wuhan, China: a descriptive study. The Lancet 395 (10223), 507-513, https://doi.org/10.1016/S0140-6736(20)30211-7.

CONEVAL, 2019. Pobreza en México. [Data set]. https://www.coneval.org.mx/Medicion/MP/Paginas/Pobreza-2018.aspx.

Consejo Nacional de Población (CONAPO), 2019. Proyecciones de la Población de los Municipios de México, 2015-2030. [Data set]. https://www.gob.mx/conapo/documentos/proyecciones-de-la-poblacion-delos-municipios-de-mexico-2015-2030.

Cordova-Villalobos, J. A., Barriguete-Melendez, J. A., Lara-Esqueda, A., Barquera, S., Rosas-Peralta, M., Hernandez-Avila, M., Leon-May, M. E. d., Aguilar-Salinas, C. A., 2008. Las enfermedades crónicas no transmisibles en México: sinopsis epidemiológica y prevención integral. Salud Pública de México 50 (5), 419-427, https://www.medigraphic.com/cgibin/new/resumen.cgi?IDARTICULO=19112.

DiBonaventura, M. D., Meincke, H., Le Lay, A., Fournier, J., Bakker, E., Ehrenreich, A., 2018. Obesity in Mexico: prevalence, comorbidities, associations with patient outcomes, and treatment experiences. Diabetes, Metabolic Syndrome and Obesity: Targets and Therapy 11, 1-10, https://doi.org/10.2147/DMSO.S129247.

Erdely, A., 2020a. COVID19mx: Culpando comorbilidades. [LinkedIn]. https://www.linkedin.com/pulse/covid19mx-culpando-comorbilidadesarturo-erdely/ (Accessed: 28 August 2020).

Erdely, A., 2020b. COVID19mx: Edad y comorbilidades. [LinkedIn]. https://www.linkedin.com/pulse/covid19mx-edad-y-comorbilidades-arturoerdely/ (Accessed: 28 August 2020).

Federación Internacional de Diabetes (FID), 2019. Atlas de la Diabetes de la FID 2019, 9th Edición. [Data set] https://www.diabetesatlas.org/.

Grasselli, G., Zangrillo, A., Zanella, A., Antonelli, M., Cabrini, L., Castelli, A., Cereda, D., Coluccello, A., Foti, G., Fumagalli, R., Iotti, G., Latronico, N., Lorini, L., Merler, S., Natalini, G., Piatti, A., Ranieri, M. V., Scandroglio, A. M., Storti, E., Cecconi, M., Pesenti, A., COVID-19 Lombardy ICU Network, 2020. Baseline Characteristics and Outcomes of 1591 Patients Infected With SARS-CoV-2 Admitted to ICUs of the Lombardy Region, Italy. JAMA 323 (16), 1574-1581, https://doi.org/10.1001/jama.2020.5394.

Guan, W.-J., Liang, W.-H., Zhao, Y., Liang, H.-R., Chen, Z.-S., Li, Y.-M., Liu, X.-Q., Chen, R.-C., Tang, C.-L., Wang, T., Ou, C.-Q., Li, L., Chen, P.-Y., Sang, L., Wang, W., Li, J.-F., Li, C.-C., Ou, L.-M., Cheng, B., Xiong, S., Ni, Z.-Y., Xiang, J., Hu, Y., Liu, L., Shan, H., Lei, C.-L., Peng, Y.-X., Wei, L., Liu, Y., Hu, Y.-H., Peng, P., Wang, J.-M., Liu, J.-Y., Chen, Z., Li, G., Zheng, Z.-J., Qiu, S.-Q., Luo, J., Ye, C.-J., Zhu, S.-Y., Cheng, L.-L., Ye, F., Li, S.-Y., Zheng, J.-P., Zhang, N.-F., Zhong, N.-S., He, J.-X., China Medical Treatment Expert Group for COVID-19, 2020. Comorbidity and its impact on 1590 patients with COVID-19 in China: a nationwide analysis. The European Respiratory Journal 55 (5), https://doi.org/10.1183/13993003.005472020.

INEGI, INSP, 2019. Encuesta Nacional de Salud y Nutrición (ENSANUT) 2018. [Data set ]. https://ensanut.insp.mx/encuestas/ensanut2018/index.php.

OECD, 2019a. Health at a Glance 2019. https://doi.org/10.1787/4dd50c09-en.

OECD, 2019b. The Heavy Burden of Obesity. https://doi.org/10.1787/67450d67-en.

Organizacion Mundial de la Salud (OMS), 2016. Informe Mundial Sobre la Diabetes. https://www.who.int/diabetes/global-report/en/.

Parant, A., 1990. World population prospects. Futuribles 141, 49-78, https://pubmed.ncbi.nlm.nih.gov/12283219/.

Proyecto Li, Roldán, N., Ángel, A., 2020. El impacto de la pandemia: 130 mil muertos en cuatro meses, solo 51 mil reconocidos por COVID. Animal Político, https://www.animalpolitico.com/2020/09/excesos-muertes-covidmexico-cifras-epidemia/ (Accessed: 2 September 2020).

Pérez-Salgado, D., Valdés Flores, J., Janssen, I., Ortiz-Hernández, L., 2012. Diagnosis and treatment of obesity among Mexican adults. Obesity Facts 5 (6), 937-946.

Romero Zavala, M., Despeghel, L., 2020. ¿Qué nos dicen las actas de defunción de la CDMX? Actualización al 9 de agosto 2020. Nexos. Taller de Datos, https://datos.nexos.com.mx/?p=1634 (Accessed: 2 September 2020).

Rosas-Peralta, M., Attie, F., 2007. Enfermedad cardiovascular: Primera causa de muerte en adultos de México y el mundo. Archivos de cardiología de México 77 (2), 91-93, http://www.scielo.org.mx/scielo.php?script=sci_abstract\&pid=S140599402007000200001\&lng=es\&nrm=iso\&tlng=es.

Rtveladze, K., Marsh, T., Barquera, S., Romero, L. M. S., Levy, D., Melendez, G., Webber, L., Kilpi, F., McPherson, K., Brown, M., 2014. Obesity prevalence in Mexico: impact on health and economic burden. Public Health Nutrition 17 (1), 233-239, https://doi.org/10.1017/S1368980013000086.

SALUD México [@SSalud_mx], 2020. Hoy en Mexico falleció la primera persona con \#COVID19. Inició sus síntomas el 9 de marzo y padecía diabetes. El Secretario de Salud expresa sus condolencias a sus familiares. Descanse en paz. [Tweet]. https://twitter.com/SSalud_mx/status/1240499937433006081?ref_src=twsrc $\% 5$ Etfw (Accessed: 9 April 2020).

SEGOB, 2020. ACUERDO por el que se establecen acciones extraordinarias para atender la emergencia sanitaria generada por el virus SARS-CoV2SEGOB. Diario Oficial de la Federación (DOF), https://www.dof.gob.mx/nota_detalle.php?codigo $=5590914 \&$ fecha $=31 / 03 /$ 2020 (Accessed: 15 April 2020).

SSA, 2018. PANORAMA EPIDEMIOLÓGICO 2018. Enfermedades No Transmisibles. OBSERVATORIO MEXICANO DE ENFERMEDADES NO TRANSMISIBLES (OMENT), https://epidemiologia.salud.gob.mx/gobmx/salud/documentos/panoOMENT/Panorama_OMENT_2018.pdf.

SSA, 2020a. 095. Inicia fase 2 por coronavirus COVID-19. Prensa, https://www.gob.mx/salud/prensa/095-inicia-fase-2-por-coronaviruscovid-19.

SSA, 2020b. Catálogo de Clave Única de Establecimientos de Salud-CLUES. http://www.dgis.salud.gob.mx/contenidos/sinais/s_clues.html.

SSA, 2020c. Datos Abiertos - Dirección General de Epidemiología. [Data set] https://www.gob.mx/salud/documentos/datos-abiertos-152127 (Accessed: 20 August 2020).

SSA, 2020d. Sistema de Información de la Secretaría de Salud. http://sinaiscap.salud.gob.mx:8080/DGIS/\#.

Stevens, A. M. H., 2020. Lessons from covid-19: visiting patients at home and assessing comorbidities. BMJ 369, https://doi.org/10.1136/bmj.m1385.

Stevens, G., Dias, R. H., Thomas, K. J. A., Rivera, J. A., Carvalho, N., Barquera, S., Hill, K., Ezzati, M., 2008. Characterizing the Epidemiological Transition in Mexico: National and Subnational Burden of Diseases, Injuries, and Risk Factors. PLOS Medicine 5 (6), e125, https://doi.org/10.1371/journal.pmed.0050125.

Wang, D., Hu, B., Hu, C., Zhu, F., Liu, X., Zhang, J., Wang, B., Xiang, H., Cheng, Z., Xiong, Y., Zhao, Y., Li, Y., Wang, X., Peng, Z., 2020a. Clinical Characteristics of 138 Hospitalized Patients With 2019 Novel Coronavirus-Infected Pneumonia in Wuhan, China. JAMA 323 (11), 10611069, https://doi.org/10.1001/jama.2020.1585.

Wang, T., Du, Z., Zhu, F., Cao, Z., An, Y., Gao, Y., Jiang, B., 2020b. Comorbidities and multi-organ injuries in the treatment of COVID-19. Lancet 395 (10228), e52, https://doi.org/10.1016/S0140-6736(20)30558-4.

World Health Organization (WHO), 2020a. WHO COVID-19 Dashboard. https://who.sprinklr.com/region/euro/country/es (Accessed: 9 April 2020).

World Health Organization (WHO), 2020b. WHO Timeline - COVID-19. https://www.who.int/news-room/detail/08-04-2020-who-timeline-covid19 (Accessed: 9 April 2020).

Yang, J., Zheng, Y., Gou, X., Pu, K., Chen, Z., Guo, Q., Ji, R., Wang, H., Wang, Y., Zhou, Y., 2020a. Prevalence of comorbidities and its effects in patients infected with SARS-CoV-2: a systematic review and metaanalysis. International journal of infectious diseases: IJID: official publication of the International Society for Infectious Diseases 94, 91-95, https://doi.org/10.1016/j.ijid.2020.03.017.

Yang, X., Yu, Y., Xu, J., Shu, H., Xia, J., Liu, H., Wu, Y., Zhang, L., Yu, Z., Fang, M., Yu, T., Wang, Y., Pan, S., Zou, X., Yuan, S., Shang, Y., 2020b. Clinical course and outcomes of critically ill patients with SARS-CoV-2 pneumonia in Wuhan, China: a single-centered, retrospective, observational study. The Lancet. Respiratory Medicine 8 (5), 475-481, https://doi.org/10.1016/S2213-2600(20)30079-5.

Zhou, F., Yu, T., Du, R., Fan, G., Liu, Y., Liu, Z., Xiang, J., Wang, Y., Song, B., Gu, X., Guan, L., Wei, Y., Li, H., Wu, X., Xu, J., Tu, S., Zhang, Y., Chen, H., Cao, B., 2020. Clinical course and risk factors for mortality of adult inpatients with COVID-19 in Wuhan, China: a retrospective cohort 
study. The Lancet 395 (10229), 1054-1062, https://doi.org/10.1016/S01406736(20)30566-3.
This article accompanies the following material:

HTML:

https://doi.org/10.22201/igg.25940694e.2020.2.73

Dashboard: https://doi.org/10.22201/igg.25940694e.2020.2.73.163

Supplement: https://doi.org/10.22201/igg.25940694e.2020.2.73.171 